\title{
14. PORE-WATER CHEMISTRY OF THE SULU AND CELEBES SEAS: EXTENSIVE DIAGENETIC REACTIONS AT SITES 767 AND 7681
}

\author{
Marta T. von Breymann, ${ }^{2}$ Peter K. Swart,${ }^{3}$ Garrett W. Brass, ${ }^{3}$ and Ulrich Berner ${ }^{4}$
}

\begin{abstract}
The combination of multiple sediment sources and varying rates of sediment accumulation in the Celebes and Sulu seas have had significant impact on the processes of diagenesis, mineralization, and pore-fluid flow. Isotopic and mass-balance calculations help elucidate the various reactions taking place in these western Pacific basins, where ash alteration and basalt-seawater interactions are superimposed on the effects of sulfate oxidation of organic carbon and biogenic methane and of dolomitization of biogenic carbonates. Based on the shape of the calcium and magnesium depth profiles, two major reactive zones have been identified. The first is located near the zone of sulfate depletion and is characterized by carbonate recrystallization, dolomitization and ash alteration reactions at both Ocean Drilling Program Sites 767 and 768 . The second reactive zone corresponds to the bottom of the sedimentary sequence and is characterized by alteration reactions in the basement (Site 767) and in the pyroclastic deposits beneath the sediment column (Site 768).
\end{abstract}

\section{INTRODUCTION}

Marginal basins experience major tectonic and paleoceanographic changes during their evolution. The timing and extent of the volcanic, collisional, and paleoceanographic events is recorded in their sedimentary sequences. During Leg 124 five sites were drilled in two marginal basins in the western Pacific: the Celebes and the Sulu seas (Fig. 1). In these environments, the combination of multiple sediment sources and varying rates of sediment accumulation have had a significant impact on the processes of diagenesis, mineralization, and pore-fluid flow. The objectives of this study were to interpret the distributions of the dissolved constituents in the pore waters, and their carbon, oxygen, and strontium isotopes, in terms of diagenetic and alteration processes. We have focused our study on two sites: Site 767 , located in the central Celebes Sea in a water depth of $4905 \mathrm{~m}$, and Site 768, located in the southeastern part of the Sulu Sea in a water depth of $4385 \mathrm{~m}$.

\section{REGIONAL SETTING}

The Celebes Sea is a small ocean basin bounded in the north by the Sulu Archipelago and in the south by the island of Sulawesi (Fig. 1). During Leg 124, basaltic basement was reached at $787 \mathrm{mbsf}$ at Site 767 . Drilling in this basin established that the volcanic basement is overlain by middle Eocene red clays, indicating that the Celebes Sea originated in an open ocean setting similar to that of the Philippine Sea. The Sulu Sea is a marginal basin located between northern Borneo and the central Philippine Archipelago. A distinct northeast-trending bathymetric high, the Cagayan Ridge, subdivides the Sulu Sea into two sub-basins. Drilling at Site 768 in the southeast basin recovered $1047 \mathrm{~m}$ of sediment and $222 \mathrm{~m}$ of basement. Analysis of these sequences has shown

\footnotetext{
${ }^{1}$ Silver, E. A., Rangin, C., von Breymann, M. T., et al., 1991. Proc. ODP, Sci. Results, 124: College Station, TX (Ocean Drilling Program).

2 Ocean Drilling Program, Texas A\&M Research Park, 1000 Discovery Drive, College Station, TX 77845 , U.S.A.

${ }^{3}$ Rosenstiel School of Marine and Atmospheric Science, University of Miami, 4600 Rickenbacker Causeway, Miami FL 33249, U.S.A.

${ }^{4}$ Bundesanstalt für Geowissenschaften und Rohstoffe, Stillweg 2, D-3000, Hannover 51, Federal Republic of Germany.
}

that the Sulu Sea originated in a back-arc setting in the late-early to early-middle Miocene, nearly concurrent with the cessation of volcanism in the Cagayan Ridge. Early outpourings of rhyolitic to dacitic pyroclastic flows marked the early formation of the basin (Rangin, Silver, von Breymann, et al., 1990).

Although the basins have different tectonic origins and ages, their proximity to volcanic arcs and continental sources has led to similar patterns of sedimentation. For example, thick continentally derived turbidites in the upper Miocene at Site 768 coincide with those seen in the Celebes Sea, suggesting a common source, very likely Borneo. These sequences correspond to a major compressive event between the Philippine Mobile Belt, and the Sulu, Palawan, and Cagayan Ridges during the middle Miocene (Rangin and Silver, this volume).

Both sites (767 and 768) are located in deep water, resulting in most cases in low-carbonate sequences. The sediments at Site 767 record deposition within a deep basin below the calcite compensation depth (CCD); carbonate turbidites are present as graded beds below 109 mbsf, and contain assemblages of foraminifers that have been redeposited from shallower depths. Site 768 records a sedimentation regime below the CCD throughout its early depositional history, followed by a rapid increase in carbonate accumulation at the Pliocene/ Pleistocene boundary (Linsley, this volume). The carbonate content of the sediments has been related to sediment source, mode of sedimentation, and changes in the CCD through time (Rangin, Silver, von Breymann, et al., 1990).

The organic carbon of the sediments in both basins is mostly of terrestrial origin, with the highest accumulation rates occurring in middle Miocene turbiditic sequences. The relative proportion of marine organic material is higher in sediments younger than upper to middle Miocene (Bertrand et al., this volume). The organic matter is characterized by low levels of maturity at Site 767, whereas Site 768 sediments reach the thermogenic hydrocarbon generation zone around 450 mbsf (Rangin, Silver, von Breymann, et al., 1990; Bertrand et al., this volume), a fact that is consistent with the higher geothermal gradient of the Sulu Sea (Berner and Bertrand, 1990).

Volcanic activity in the arcs that surround these basins results in extensive accumulation of air-fall ash and pyroclas- 


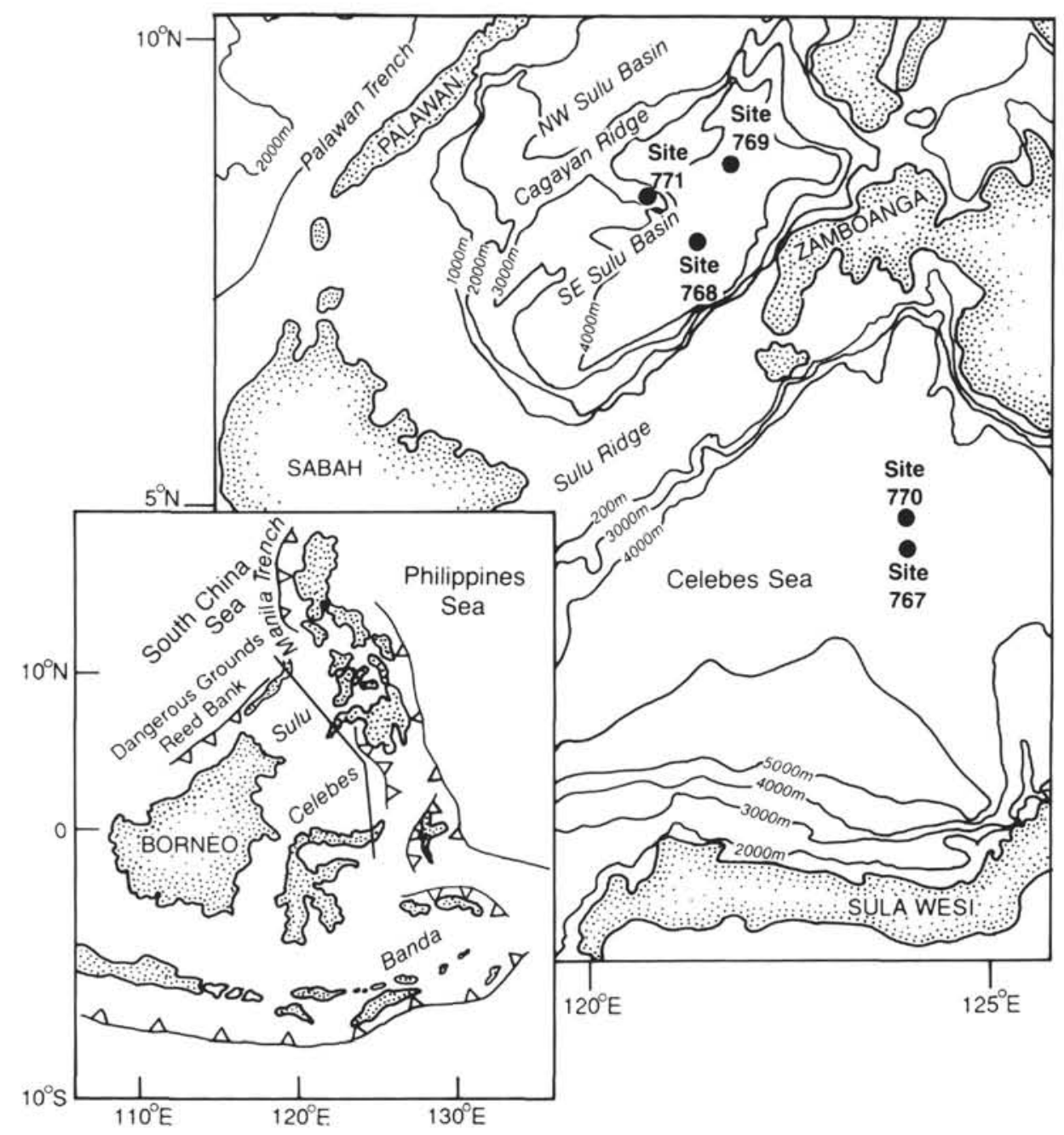

Figure 1. Location map for sites drilled in the Celebes and Sulu seas, from Rangin, Silver, von Breymann et al., 1990.

tic flows in the Celebes and Sulu Seas (Pubellier et al., this volume). Thick, continentally derived turbidites occur at both Sites 767 and 768 in the upper middle Miocene, but are not present in the sections of Sites 769 and 770 . To better evaluate the effect of these sequences on the interstitial water chemistry we have used, in some instances, comparisons with data from the sites located on bathymetric highs (Sites 769 and 770), which are isolated from the deposition of turbidites of terrigenous detritus.

\section{METHODS}

Interstitial fluids were collected by pressure filtration. Dissolved sulfate, alkalinity, ammonium, silica, calcium, and magnesium were measured within $24 \mathrm{hr}$ of sample collection. Methane contents were estimated by analysis of head space samples after incubation of the sediment at $60^{\circ} \mathrm{C}$. The carbonate content of the sediments was measured coulometrically, and the total organic carbon (TOC) was obtained by RockEval determinations. These analyses were done on board the JOIDES Resolution; the sample handling and the analytical techniques utilized are described in Rangin, Silver, von Breymann, et al. (1990).

Dissolved strontium and potassium were measured by atomic absorption spectrometry after appropriate sample di- lution and matrix modification. The $\delta^{13} \mathrm{C}$ measurements on total dissolved $\mathrm{CO}_{2}$ were carried out in the BGR laboratories, Hannover, FRG, using a Finnigan MAT 250 mass spectrometer and are reported relative to the PDB (Pee Dee Belemnite) standard. ${ }^{18} \mathrm{O} /{ }^{16} \mathrm{O}$ ratios in the pore fluids were determined using a Finnigan-MAT 251 at the University of Miami, and are reported in per mill $\left(\%_{0}>\right)$ deviation from SMOW. For this determination, $1 \mathrm{~cm}^{3}$ of sample was equilibrated with $\mathrm{CO}_{2}$ at $25^{\circ} \mathrm{C}$ for a period of 12 to $24 \mathrm{hr}$, after the method of Epstein and Mayeda (1954). Results were normalized to standards prepared and equilibrated at the same time.

\section{RESULTS}

The downhole distributions of alkalinity, sulfate, ammonium, silica, calcium, magnesium, potassium, and strontium at Sites 767 and 768 are shown in Figure 2, based on data listed in Table 1. Changes in gradient of the calcium and magnesium profiles suggest two main reaction zones: (1) the ash-carbonate-bearing sediments in the upper $200-300 \mathrm{~m}$ at both sites, and (2) the basalts at Site 767 and volcanogenic deposits overlying basement at Site 768 .

The concentration-depth profiles of calcium and magnesium are nonlinearly correlated throughout the sediment column. The downhole magnesium distributions suggest that 


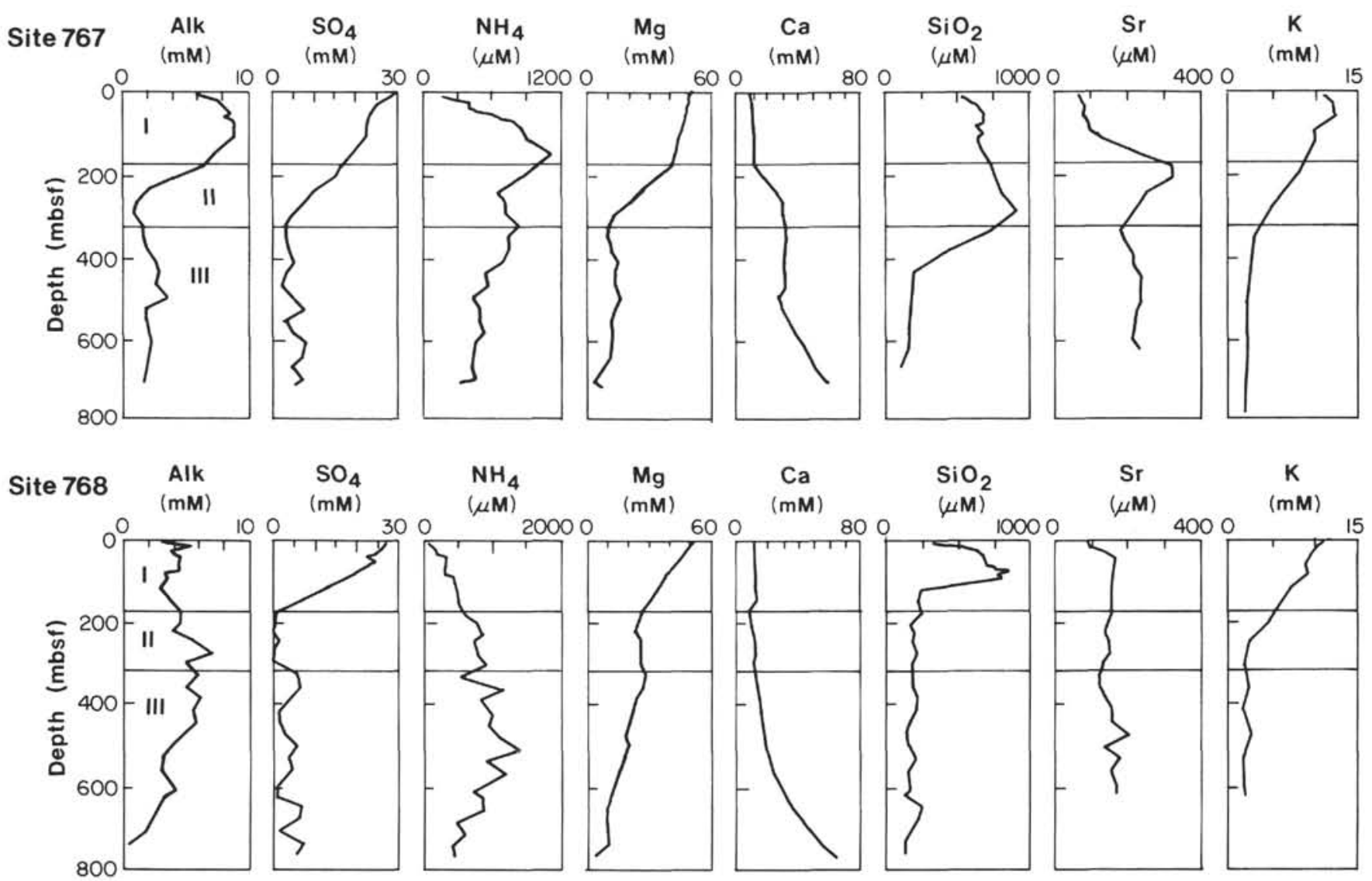

Figure 2. Downcore distributions of dissolved alkalinity, sulfate, ammonium, magnesium, calcium, silica, strontium, and potassium at Sites 767 and 768.

consumption of this element is largely taking place in the upper portion of the sedimentary sequences at both sites. On the other hand, the dissolved-calcium profiles indicate that reactions in the underlying basalts are an important source for this element, and that reactions in the sediments contribute to a lesser extent to the calcium increase relative to the magnesium consumption. Within the sediment column, the effects of alteration of volcanic material are superimposed on the diagenetic alteration of biogenic carbonates.

It is difficult to quantitatively assign changes in the concentration of dissolved constituents of the pore fluids to diagenetic reactions in the sediments and/or alteration reactions in the basement. These exercises have been somewhat successful when applied to homogeneous sediments of geochemically simple areas. For example, carbonate recrystallization models have been used to explain changes in the calcium and strontium concentrations in several deep-sea carbonate sediment sections (Baker et al., 1982). McDuff and Gieskes (1976) and Gieskes and Lawrence (1981) have modeled changes in the dissolved calcium, magnesium, and oxygen isotope profiles of pore fluids in deep-sea sediments in areas where there is little effect from organic matter oxidation on the alkalinity, calcium, and magnesium distributions.

In the western Pacific basins where ash alteration and basalt-seawater interactions are superimposed on the effects of the sulfate reduction and dolomitization of biogenic carbonates, a fully quantitative evaluation of all the geochemical processes is hardly possible. Nevertheless, in the following sections we have used isotopic and mass-balance calculations to help elucidate the various reactions taking place at Sites 767 and 768. These calculations represent a semiquantitative approach constrained by the complex and variable nature of the sediments in this environment.

\section{Dissolved Strontium and Carbonate Recrystallization Estimates}

Both sites (767 and 768) show small increases in the dissolved strontium concentration downcore (Fig. 2). Such increases have been observed at other DSDP and ODP sites and have been attributed to recrystallization of biogenic carbonates to inorganic calcite, with the consequent release of strontium to the pore fluids (Baker et al., 1982). As the dissolved strontium and sulfate concentrations are below celestite saturation, the diffusive flux of strontium from the sediment and the degree of carbonate recrystallization at Sites 767 and 768 may be estimated (Baker, 1986; Stout, 1985; Swart and Guzikowski, 1988). In the method outlined by Baker (1986), the strontium flux out of or into the sediments is summed over the time interval represented by two successive pore-water samples. The flux is given by

$$
\text { Flux }=-D_{\mathrm{b}} \cdot d c / d x
$$

where $D_{\mathrm{b}}$ is the diffusion coefficient, here assumed to be $4 \times$ $10^{-6} \mathrm{~cm}^{2} / \mathrm{s}, d c$ is the concentration gradient, and $d x$ represents the depth interval in question.

If we assume that the average $\mathrm{Sr} / \mathrm{Ca}$ molar ratio of the original biogenic sediment is $2 \times 10^{-3}$, a typical value for pelagic calcite (Baker, 1982), then the total amount of stron- 
Table 1. Concentration of dissolved constituents in the pore fluids of (A) Site 767 and (B) Site 768.

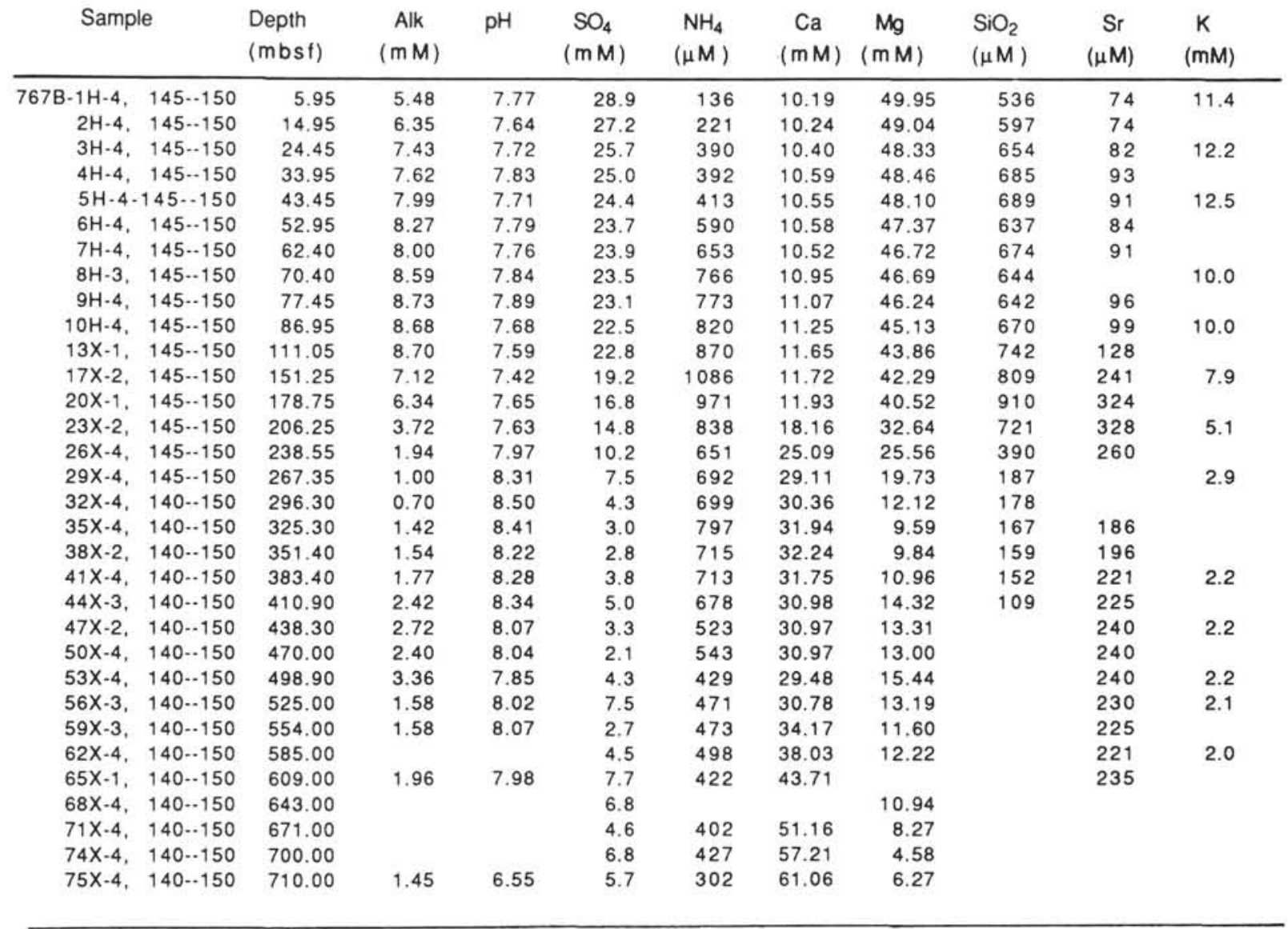

tium for each interval in the sediment can be calculated using the calcium carbonate data shown in Figure 3 . We have assumed an average calcium carbonate content of $2 \%$ for the upper 120 mbsf and $25 \%$ for the lower portion of the holes at Site 767. For the upper sections of Site 768 we have assumed an average value of $25 \%$, and a $2 \%$ carbonate content for the sediments below 120 mbsf. By comparing the fractional change in dissolved strontium with that available in the sediment, we have estimated the amount of recrystallization that has occurred during the period represented by the sampling interval. By further assuming that there has been no significant change in the distribution of dissolved strontium with time, the percent carbonate recrystallized over a given section may be estimated by summing all the intervals over which there are pore-water data available. The results of this exercise are shown in Figure 4. Using different concentrations of carbonate will result in significantly different estimates of recrystallization. For example, if the carbonate content in the upper 180 mbsf at Site 767 is reduced from $2 \%$ to $0.5 \%$, the estimated rate of recrystallization increases so that the carbonate component of the sediment is expected to be completely recrystallized between 150 and $180 \mathrm{mbsf}$, which corresponds to the maximum in the dissolved strontium profile (Fig. 2). Similarly, if at Site 768 the carbonate content used in the previous calculations is reduced from $2 \%$ to $1 \%$, the carbonate component of the sediment will be $100 \%$ recrystallized by 500 mbsf (Fig. 4).

It is important to note that this method does not take into account the amount of strontium incorporated into any diagenetic calcite, nor any contributions to the pore fluids by diagenetic alteration of igneous minerals. The latter source may be considerable, particularly in the deepest sedimentary sequences as evidenced by the strontium isotopic composition of the pore fluids discussed in the following section. The estimates given in Figure 4 are extremely dependent upon the assumptions listed above; nevertheless this calculation allows us to place constraints on the system. Limits on the degree of carbonate recrystallization and the sedimentary sections where this reaction is more likely to be occurring are useful for evaluating the oxygen and carbon isotope distributions.

\section{Oxygen and Strontium Isotopes}

The ${ }^{87} \mathrm{Sr} /{ }^{86} \mathrm{Sr}$ ratio in the pore fluids is shown relative to the Burke et al. (1982) seawater curve in Figure 5. Normally in pelagic sediments dominated by carbonates, the ${ }^{87} \mathrm{Sr} /{ }^{86} \mathrm{Sr}$ distribution lies close to this curve. Sites 767 and 768 might have experienced a significant contribution of redeposited Miocene carbonates that can have a ${ }^{87} \mathrm{Sr} /{ }^{86} \mathrm{Sr}$ ratio as low as 0.7086 . Thus, although in the upper $200 \mathrm{mbsf}$ of Site 767 the strontium isotope values could represent recrystallization of Miocene carbonates, the significant depletion observed in the deepest analyzed sample at this site, and in most of Site 768 samples, indicates that there has been isotopic exchange between the pore fluids and the volcanic sequences. Figure 6 shows the depth distribution of the ${ }^{87} \mathrm{Sr} /{ }^{86} \mathrm{Sr}$ values superimposed to the dissolved silica profiles at both Sites 767 and 768 . The minima in these profiles coincide with a zone of ash alteration characterized by the replacement of volcanic glass by an authigenic smectite-phillipsite assemblage (Desprairies et al., this volume). This diagenetic zone is synchronous in 
Table 1 (continued).

\begin{tabular}{|c|c|c|c|c|c|c|c|c|c|c|c|}
\hline & imple & $\begin{array}{l}\text { Depth } \\
\text { (mbsf) }\end{array}$ & $\begin{array}{c}\text { Alk } \\
(\mathrm{mM})\end{array}$ & $\mathrm{pH}$ & $\begin{array}{c}\mathrm{SO}_{4} \\
(\mathrm{mM})\end{array}$ & $\begin{array}{l}\mathrm{NH}_{4} \\
(\mu \mathrm{M})\end{array}$ & $\begin{array}{c}\mathrm{Ca} \\
(\mathrm{mM})\end{array}$ & $\begin{array}{c}\mathrm{Mg} \\
(\mathrm{mM})\end{array}$ & $\begin{array}{l}\mathrm{SiO}_{2} \\
(\mu \mathrm{M})\end{array}$ & $\begin{array}{c}\mathrm{Sr} \\
(\mu \mathrm{M})\end{array}$ & $\begin{array}{c}K \\
(\mathrm{~m} M)\end{array}$ \\
\hline 768B-1H-2, & $145 \cdots 150$ & 2.95 & 3.01 & 7.56 & 27.1 & 26 & 10.86 & 51.48 & 411 & 91 & 10.1 \\
\hline $2 \mathrm{H}-5$, & $145-150$ & 11.45 & 4.99 & 7.56 & 27.3 & 68 & 11.02 & 50.07 & 542 & 98 & \\
\hline $3 \mathrm{H}-5$, & $145--150$ & 20.95 & 3.91 & 7.50 & 26.2 & 116 & 11.06 & 48.85 & 625 & 127 & 9.3 \\
\hline $4 \mathrm{H}-5$, & $145-150$ & 30.45 & 3.83 & 7.48 & 24.9 & 146 & 10.95 & 46.76 & 655 & 148 & \\
\hline $5 \mathrm{H}-4$, & $145-150$ & 38.45 & 4.40 & 7.45 & 22.8 & 284 & 11.24 & 46.23 & 674 & 167 & 8.9 \\
\hline $6 \mathrm{H}-5$, & $145 \cdots 150$ & 49.45 & 4.36 & 7.41 & 23.9 & 285 & 11.39 & 44.67 & 689 & 167 & \\
\hline $7 \mathrm{H}-5$, & $145 \cdots 150$ & 58.95 & 4.38 & 7.51 & 22.7 & 280 & 11.43 & 42.90 & 751 & 163 & 8.6 \\
\hline $8 \mathrm{H}-5$, & $145 \cdots 150$ & 68.45 & 4.35 & 7.41 & 21.1 & 277 & 11.43 & 41.17 & 836 & 167 & \\
\hline 9H-5, & $140 \cdots 150$ & 77.95 & 3.29 & 7.49 & 20.0 & 277 & 11.62 & 39.41 & 765 & 160 & 8.8 \\
\hline $10 \mathrm{H}-5$, & $140 \cdots 150$ & 87.45 & 3.34 & 7.49 & 19.1 & 419 & 11.94 & 37.68 & 793 & 158 & \\
\hline $13 \mathrm{H}-5$, & $140 \cdots 150$ & 115.95 & 2.81 & 7.50 & 13.0 & 453 & 12.00 & 33.86 & 230 & 153 & 6.7 \\
\hline $16 \mathrm{H}-5$, & $140--150$ & 144.45 & 3.56 & 7.84 & 7.2 & 488 & 12.56 & 30.78 & 206 & & \\
\hline $19 \mathrm{H}-5$, & $140--150$ & 172.90 & 4.42 & 7.70 & 0.8 & 561 & 9.14 & 26.75 & 224 & 153 & \\
\hline $22 \mathrm{H}-4$, & $140 \cdots 150$ & 198.70 & 4.44 & 8.35 & 0.2 & 748 & & & 158 & 146 & 4.6 \\
\hline $26 \mathrm{X}-2$, & $140=150$ & 222.20 & 3.94 & 7.87 & 0.0 & 814 & 10.24 & 23.05 & 179 & 139 & \\
\hline $28 x-4$, & $140--150$ & 244.50 & 5.42 & 8.12 & 1.4 & 738 & 11.57 & 24.86 & 171 & 146 & 2.5 \\
\hline $31 \times-5$, & $140--150$ & 274.90 & 6.69 & 7.87 & 0.0 & 751 & 11.95 & 25.19 & 198 & 151 & \\
\hline $34 X-2$, & $140--150$ & 299.30 & 4.84 & 7.80 & 0.0 & 847 & 11.10 & 25.09 & 166 & 134 & 2.0 \\
\hline $37 \times-2$, & $140--150$ & 328.40 & 5.72 & 7.85 & 5.4 & 506 & 11.97 & 27.45 & & 127 & \\
\hline $768 \mathrm{C}-1 \mathrm{R}-3$, & $140 \cdots 150$ & 357.60 & 5.05 & 7.82 & 6.5 & 1134 & 12.54 & 26.72 & 172 & 127 & 2.5 \\
\hline 4R-1. & $140--150$ & 383.50 & 5.91 & 7.82 & 4.1 & 825 & 13.56 & 23.35 & 211 & 136 & \\
\hline 7R-3, & $140-150$ & 415.50 & 5.44 & 7.89 & 1.1 & 977 & 14.94 & 21.80 & 201 & 155 & 1.8 \\
\hline 10R-3, & $140--150$ & 444.30 & 5.66 & 8.01 & 1.2 & 951 & 16.52 & 20.15 & 156 & 158 & \\
\hline 13R-3, & $140 \cdots 150$ & 473.30 & 4.70 & 8.04 & 2.4 & 1093 & 17.40 & 18.09 & 134 & 196 & 2.7 \\
\hline 16R-1, & $140--150$ & 499.30 & 3.87 & 7.98 & 5.3 & 1378 & 18.86 & 19.06 & 146 & 136 & \\
\hline 19R-1, & $140 \cdots 150$ & 528.30 & 3.14 & 7.75 & 3.1 & 911 & 20.79 & 17.37 & 187 & 170 & 1.9 \\
\hline 22R-2, & $140 \cdots 150$ & 558.70 & 2.94 & 7.77 & 4.1 & 1155 & 22.23 & 14.83 & 148 & 153 & \\
\hline 26R-4, & $140 \cdots 150$ & 600.50 & 4.03 & 7.74 & 0.7 & 714 & & & 158 & 165 & 1.8 \\
\hline 28R-4, & $140 \cdots 150$ & 619.80 & 3.12 & 7.93 & 0.3 & 860 & 31.80 & 10.60 & 121 & 167 & 2.1 \\
\hline 31R-3, & $140-150$ & 647.20 & & & 6.4 & 846 & 35.60 & 9.07 & 236 & & \\
\hline 34R-5, & $140 \cdots 150$ & 679.20 & & & 6.2 & 468 & 42.19 & 9.00 & 207 & & \\
\hline 34R-4, & $140-150$ & 706.70 & 1.67 & 7.31 & 1.8 & 568 & & & & & \\
\hline 40R-3, & $140 \cdots 150$ & 734.33 & 0.59 & 7.41 & 6.9 & 405 & 54.04 & 9.09 & 127 & & \\
\hline 43R-2, & $140--150$ & 761.40 & & & 5.2 & 412 & 63.28 & 3.30 & 130 & & \\
\hline
\end{tabular}

both basins, and corresponds to tephra layers dated at 3.5 to $4 \mathrm{Ma}$ (Desprairies et al., this volume).

The oxygen isotopic composition of the pore fluids decreases from approximately $0 \%$ SMOW to values between -2 $\% 0$ and $-3 \%$ (Fig. 6). We have estimated the effect of carbonate diagenesis upon the $\delta^{18} \mathrm{O}$ of the pore fluids at Site 767 , using the estimates of carbonate recrystallization presented earlier, a geothermal gradient of $77^{\circ} \mathrm{C} / \mathrm{km}$ and carbonate contents between $10 \%$ and $60 \%$. Porosity is assumed to decrease from $80 \%$ to $40 \%$ by a depth of 800 mbsf (Rangin, Silver, von Breymann, et al., 1990). The results of this calculation indicate that carbonate recrystallization has a negligible influence on the oxygen isotopic composition of the pore waters. The higher geothermal gradient of Site 768 $\left(127^{\circ} \mathrm{C} / \mathrm{km}\right.$, Vollbrecht and Kudrass, 1990) will result in an increase the $\delta^{18}$ values in the lower portions of the section. Formation of opal-CT from biogenic silica would similarly increase the pore-water $\delta^{18} \mathrm{O}$, therefore diagenetic reactions involving biogenic carbonates and silica are not likely to be responsible for the observed trend in the oxygen isotope distribution.

The most favorable diagenetic reactions for lowering the $\delta^{18} \mathrm{O}$ of the pore waters involve converting volcanic ash to clay minerals and the alteration of Layer 2 basalts (Lawrence et al., 1979). Such reactions must be responsible lowering of the $\delta^{18} \mathrm{O}$ of the fluids at Sites 767 and 768 . The $\delta^{18} \mathrm{O}$ of the pore fluids has been used in conjunction with the isotopic composition of authigenic minerals to determine that alteration of

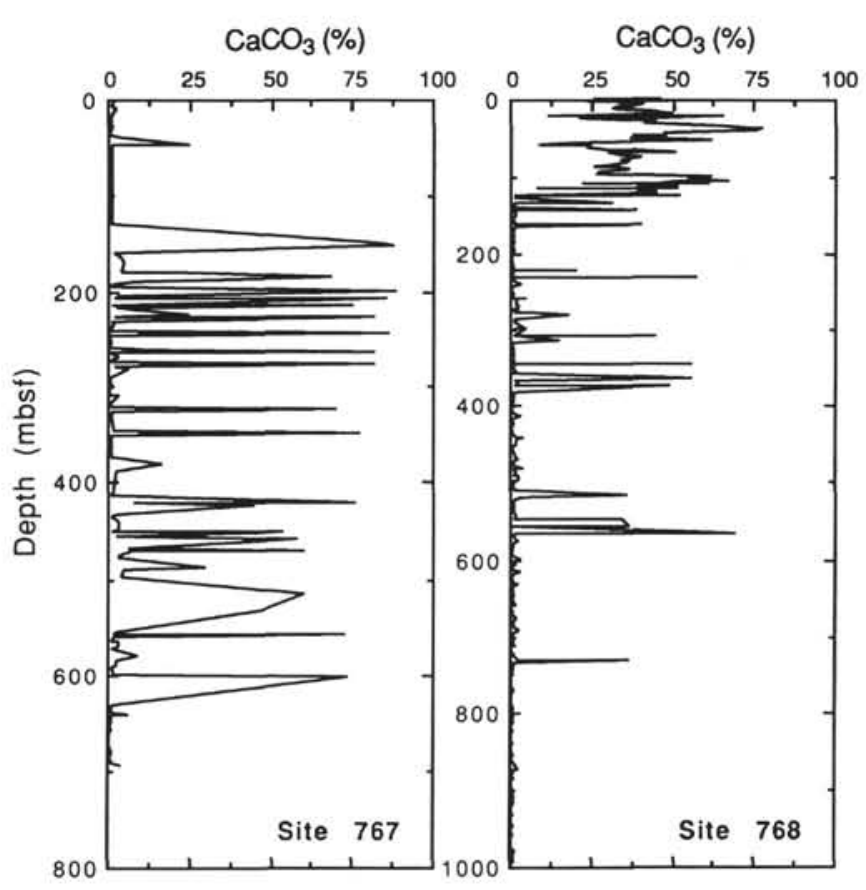

Figure 3. Carbonate content of sediments from Sites 767 and 768. Data from Rangin, Silver, von Breymann, et al., 1990./ 


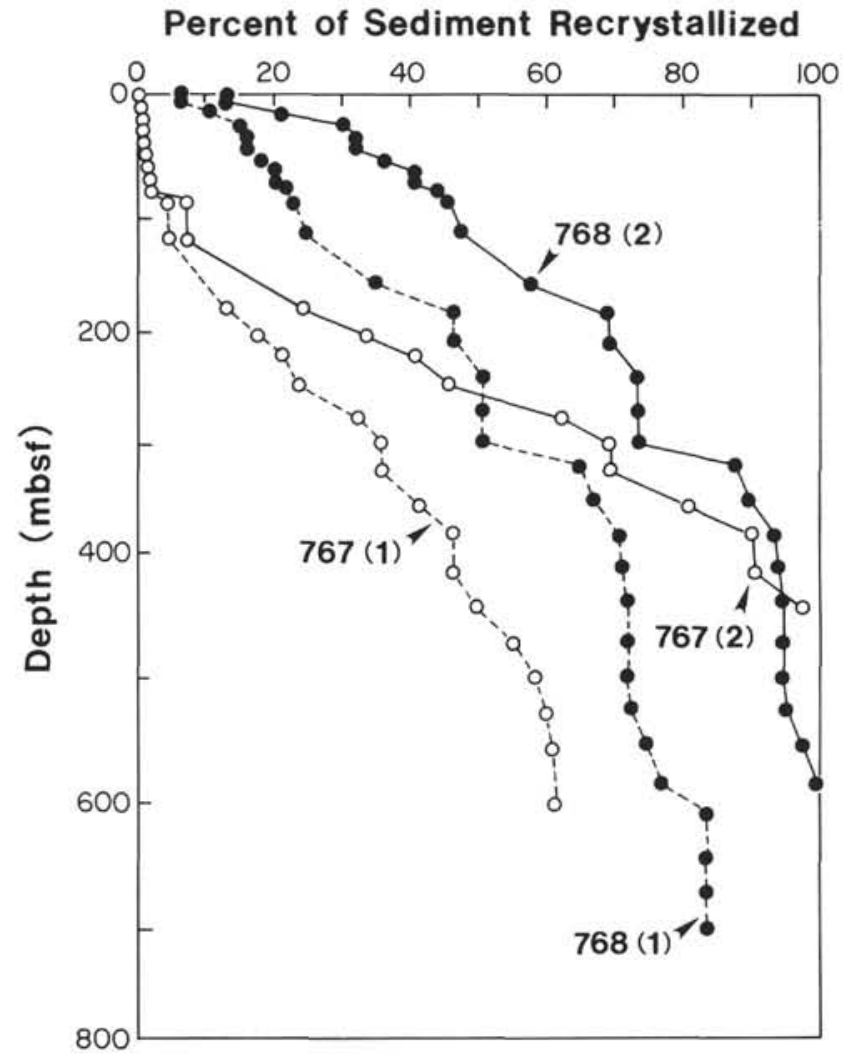

Figure 4. Degree of recrystallization calculated for the carbonate components at Sites 767 and 768 using parameters discussed in the text. Data for Site 767 example (1) denote estimates using a carbonate content of $2 \%$ over the upper $120 \mathrm{mbsf}$, while Site 767 (2) represents a content of $0.5 \%$ over the same interval. For Site 768, example (1) was calculated using a content of $2 \%$ below 120 mbsf, whereas for example (2) we used a value of $1 \%$ over the same interval.

ashes at these sites occurs under low-temperature conditions (Despraires et al., this volume).

\section{Carbon Isotopes}

The $\delta^{13} \mathrm{C}$ of the dissolved $\Sigma \mathrm{CO}_{2}$ in the pore fluids are presented in Table 2 and Figure 7. In this figure, downcore distributions of dissolved sulfate, strontium, and methane are included for comparison. Of particular significance are the light values of $\delta^{13} \mathrm{C}$ in the deeper samples analyzed, which have values for the $\Sigma \mathrm{CO}_{2}$, of $-19 \%$ at Site 767 and of $-42 \% \circ$ at Site 768 . The lightest value that could reasonably be explained by oxidation of organic carbon is $-22 \%$, which corresponds to the value measured for the sedimentary organic carbon in this area (Lallier-Verges et al., this volume). The $\delta^{13} \mathrm{C}$ distribution observed in the pore fluids of various recent and ancient anoxic marine environments has been explained by a mixing process between buried oceanic dissolved carbonate $\left(\delta^{13} \mathrm{C}=\right.$ $+0.5 \%$ ) , metabolic $\mathrm{CO}_{2}$ generated from mineralization of organic carbon $\left(\delta^{13} \mathrm{C}=-22 \%\right.$ ) and dissolution/recrystallization of fossil carbonates $\left(\delta^{13} \mathrm{C}=+2 \%\right.$ ) (McCorkle, 1987; Emerson and Bender, 1981). Additionally, anaerobic methane oxidation is now well established as an early diagenetic process in reducing sediments (Devol, 1983; Whiticar and Faber, 1986), and has been shown to result in extremely low $\delta^{13} \mathrm{C}$ values in the pore fluids of hemipelagic environments and in the pore fluids expelled from the Oregon accretionary margin (Suess and Whiticar, 1989).

The low $\delta^{13} \mathrm{C}$ values of the dissolved $\Sigma \mathrm{CO}_{2}$ measured in the Celebes and Sulu Seas indicate that methane oxidation is not restricted to depositional basins underlying areas of high primary productivity or accretionary prism settings, but it also occurs in these deep basins where terrestrial turbiditic deposits lead to the accumulation of high levels of biogenic methane $\left(\delta^{13} \mathrm{C}=-70 \%\right.$, Berner and Bertrand, this volume). Subsequent oxidation of this light carbon source will result ${ }^{13} \mathrm{C}$ depleted $\mathrm{CO}_{2}$ as measured here. The generally low organic content of these sediments precludes sulfate depletion, allowing this electron acceptor to be available to oxidize the upwardly diffusing $\mathrm{CH}_{4}$. This is further illustrated by comparing the total organic carbon, methane, and sulfate distributions of the deep basin (Sites 767 and 768), with those of sites drilled in bathymetric highs (Sites 770 and 769) where no turbiditic deposits occur and no significant accumulation of methane was observed (Fig. 8).

The changes in the $\delta^{13} \mathrm{C}$ of the pore fluids (Fig. 7) can be explained by a combination of mechanisms, namely: carbonate recrystallization, organic matter degradation, and sulfate oxidation of methane. For a detailed look at these processes, we have separated the upper $340 \mathrm{mbsf}$ of Site 767 into three intervals, as shown in Figure 7A. Interval Ia is characterized by sediments of very low carbonate content; the $\delta^{13} \mathrm{C}$ of the pore fluids in this interval corresponds to oxidation of particulate organic matter $\left(\delta^{13} \mathrm{C}-20 \%\right.$ to $-22 \%$ ). Recrystallization of the carbonate turbidites below 140 mbsf was demonstrated by using the dissolved strontium distribution as discussed earlier (Fig. 4). This process results in input of dissolved $\mathrm{CO}_{2}$ with $\delta^{13} \mathrm{C}$ of $0 \% \pm 2 \%$ to the pore fluids (Interval Ib). The decrease in dissolved sulfate in Intervals $\mathrm{Ib}$ and $\mathrm{II}$ is largely driven by methane oxidation at about 340 mbsf, which results in a sharp decrease in $\delta^{13} \mathrm{C}$ values of the pore fluids in Interval II.

At Site 768 (Fig. 7B) the $\delta^{13} \mathrm{C}$ of the dissolved $\mathrm{\Sigma CO}_{2}$ in Interval Ia has values very similar to the buried seawater $\left(\delta^{13} \mathrm{C}\right.$ $=-2 \pm 1 \%$ ) , and probably represents recrystallization reactions of these carbonate-rich sediments (Fig. 4). There is apparently very little of an isotope signature resulting from the oxidation of particulate organic carbon, which suggests that the sulfate profile is driven mostly by diffusion to the zone of methane oxidation. This is supported by the relationship between sulfate and ammonium (Fig. 9). As methane oxidation generates no ammonium at all, there is a lot more sulfate consumed relative to the amount of ammonium generated at this site relative to Interval Ia of Site 767, where sulfate is consumed by the oxidation of sedimentary organic carbon. The extremely negative $\delta^{13} \mathrm{C}$ values in Interval Ia at Site 768 clearly indicate that the dissolved $\mathrm{CO}_{2}$ is being generated by sulfate oxidation of methane $\left(\delta^{13} \mathrm{C}=-74 \pm 4 \%\right.$, Berner and Bertrand, this volume).

\section{DISCUSSION}

Two major "reactive-zones" have been identified at Sites 767 and 768 based on the shape of the calcium and magnesium depth profiles that correspond to the base of Intervals I and III (Fig. 2). A sedimentary reactive-zone is located near the zone of sulfate depletion and is characterized by carbonate recrystallization/dolomitization reactions and by ash alteration in Interval I in both sites. The second reactive-zone corresponds to alteration reactions in the basement (Site 767) and pyroclastic flows beneath the sediment column (Site 768) and determines the geochemistry of the pore fluids in Interval III. Both reactive zones may involve precipitation of carbonates and the formation of authigenic clays. 


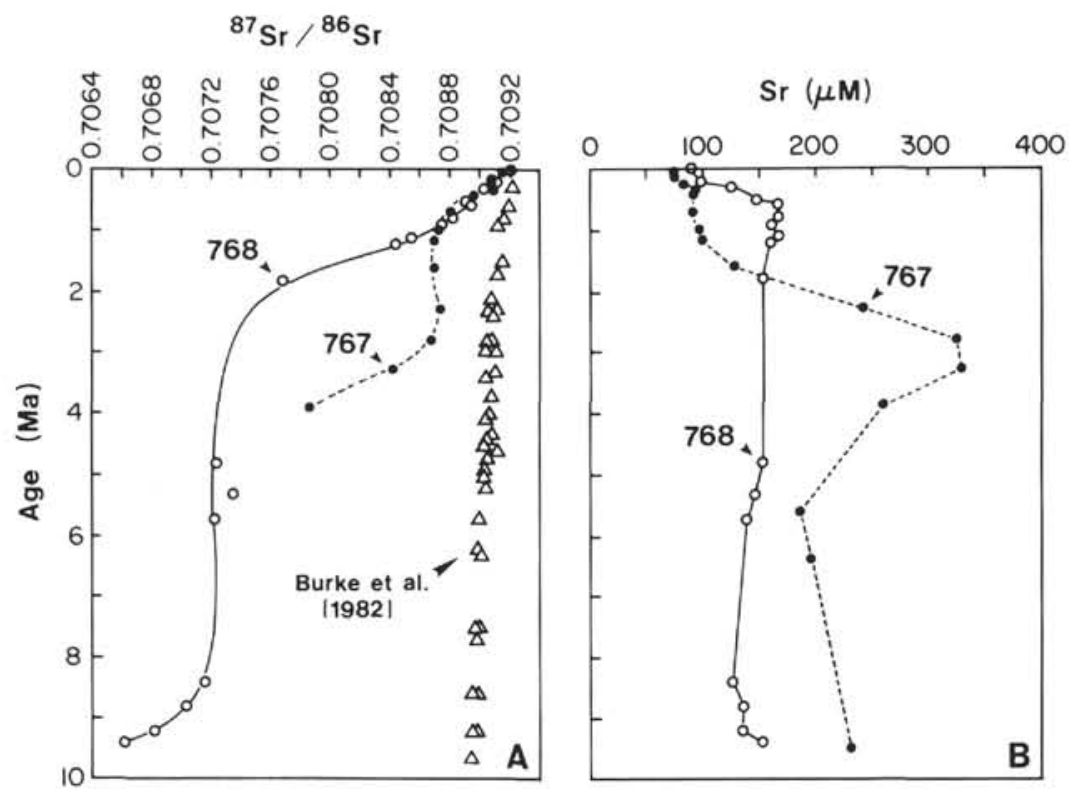

Figure 5. (A) Strontium isotopic composition of the pore fluids vs. age at Sites 767 and 768 relative to the Burke et al. (1982) seawater curve. In normal pelagic carbonatedominated sediments the ${ }^{87} \mathrm{Sr} /{ }^{86} \mathrm{Sr}$ distribution lies close to this curve. (B) Dissolved strontium content of the pore fluids.

\section{Interval I}

The carbon isotopes of the carbonates and pore waters in Sites 767 and 768 are indicative of reactions involving carbonate recrystallization partly driven by sulfate oxidation of methane. Carbonate recrystallization is also evident by the dissolved strontium distribution. Dolomitization reactions are inferred based on petrographic and XRD identification of dolomites concurrent with the onset of methane accumulations and depletion of sulfate (von Breymann and Berner, 1990). These reactions involve changes in the calcium and magnesium distributions. This interval is coincident with accumulations of ash at both Sites 767 and 768 . Alteration of this material was evident by petrographic observations, and is probably responsible for the depletion of dissolved silica (Figs. 2 and 6) and the poor preservation of diatoms in these basins (Rangin, Silver, von Breymann, et al., 1990).

At Site 768 , the $8^{13} \mathrm{C}$ of the dissolved $\mathrm{CO}_{2}$ and the sulfateammonium relationship (Fig. 9) suggest a very small contribution to the system by oxidation of sedimentary organic matter, so that the carbon isotope distribution is controlled mostly by carbonate recrystallization and by sulfate oxidation of methane, as given by

$$
\mathrm{CH}_{4}+\mathrm{SO}_{4}^{2-}=\Sigma \mathrm{CO}_{2}+2 \mathrm{H}_{2} \mathrm{O}+\mathrm{S}^{2-}
$$

Because there is no change in the calcium concentration in the pore fluids in Interval, we postulate that dolomitization is occurring by the following reaction:

$$
\begin{gathered}
\mathrm{CaCO}_{3}+\mathrm{Mg}^{2+}+2 \mathrm{HCO}^{3-}=\mathrm{CaMg}_{\left(\mathrm{CO}_{3}\right)_{2}+\mathrm{\Sigma CO}_{2}+} \\
\mathrm{H}_{2} \mathrm{O}
\end{gathered}
$$

Based on these relationships we are able to model these processes very simply in terms of changes in dissolved sulfate $\left(\Delta \mathrm{SO}_{4}^{2-}\right)$, so that

$$
\Delta \mathrm{SO}_{4}^{2-}=1 / 2 \Delta \mathrm{Mg}^{2+}-\Delta \Sigma \mathrm{CO}_{2}
$$

where $\Delta \Sigma \mathrm{CO}_{2}$ and $\Delta \mathrm{Mg}^{2+}$ are the changes in total dissolved $\mathrm{CO}_{2}$ (estimated from alkalinity and $\mathrm{pH}$ values) and magnesium relative to seawater values. Figure 10 shows the values for $\Delta \mathrm{SO}_{4}{ }^{2-}$ estimated using equation (4) vs. the $\Delta \mathrm{SO}_{4}{ }^{2-}$ values measured in the pore fluids. The good correspondence shown in this figure suggests that the main mechanisms controlling the dissolved alkalinity, sulfate, and magnesium distributions may be represented by equations (2) and (3).

At Site 767, however, the situation is more complex. As discussed in relation to the $\delta^{13} \mathrm{C}$ distributions, the upper 340 mbsf at this site can be subdivided into three intervals (Fig. $7 \mathrm{~A})$. In Interval Ia, the main process is oxidation of sedimentary organic carbon as evidenced by the $\delta^{13} \mathrm{C}$ values of $-10 \pm$ $2 \%$. In this interval, the changes in dissolved calcium and magnesium are small and the changes in alkalinity can be explained in terms of microbial degradation of organic carbon by sulfate reduction:

$$
2\left[\mathrm{CH}_{2} \mathrm{O}\left(\mathrm{NH}_{4}\right)_{\mathrm{x}}\right]+\mathrm{SO}_{4}{ }^{-2}=2 \mathrm{\Sigma CO}_{2}+2 \mathrm{H}_{2} \mathrm{O}+
$$

where $\mathrm{x}$ represents the $\mathrm{C} / \mathrm{N}$ regeneration ratio of the sedimentary organic carbon, and $\Sigma \mathrm{CO}_{2}$ is produced in a $1: 2$ ratio relative to the amount of sulfate being consumed. Intervals Ib and II are characterized by recrystallization of carbonates, carbonate generation by methane oxidation, and calcium increases relative to magnesium consumption in a $2: 1$ ratio (Fig. 2). These observations can be explained if dolomitization was occurring by the following reaction:

$$
\begin{gathered}
\left.3 \mathrm{CaCO}_{3}+2 \mathrm{Mg}^{2+}+2 \mathrm{HCO}^{3-}=2 \mathrm{CaMg}^{2-} \mathrm{CO}_{3}\right)_{2}+\mathrm{Ca}^{2+}+ \\
\mathrm{CO}_{2}+\mathrm{H}_{2} \mathrm{O} .
\end{gathered}
$$

Using equations (2) and (6), the change in sulfate can be approximated by 
A
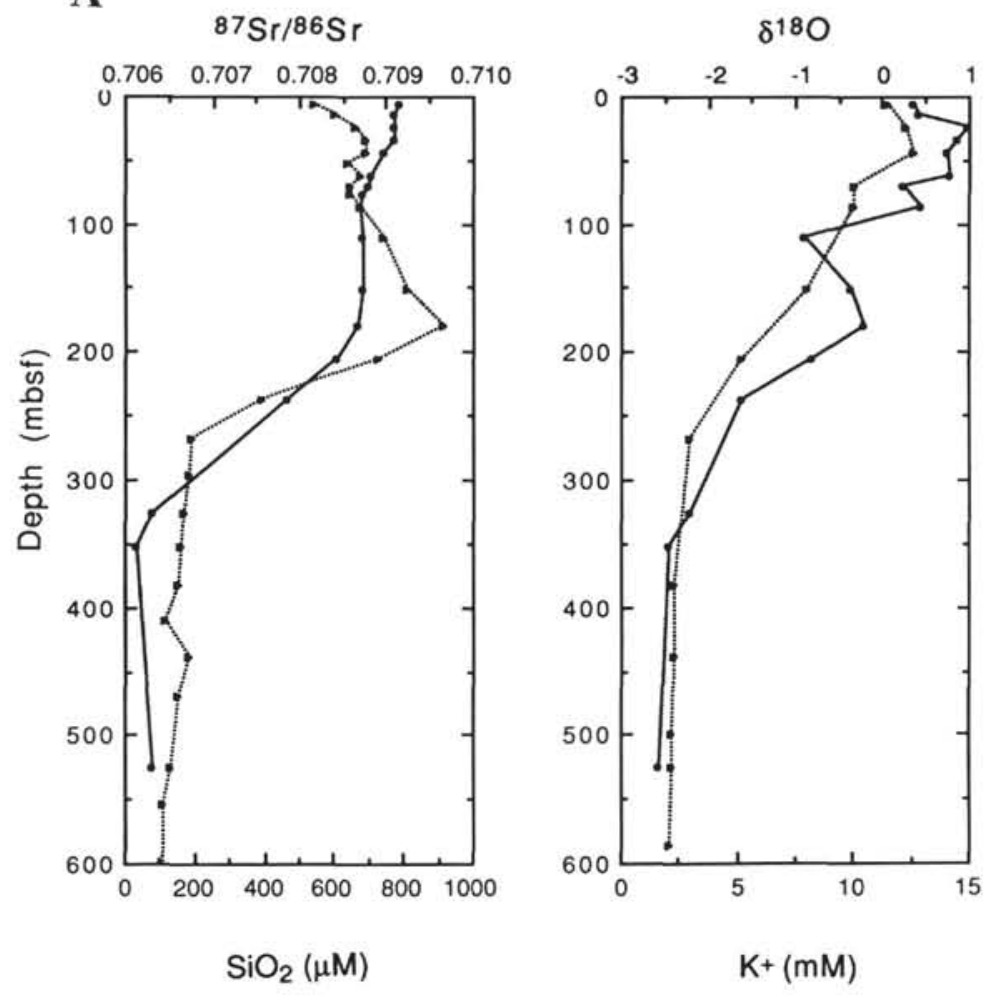

$\mathbf{B}$
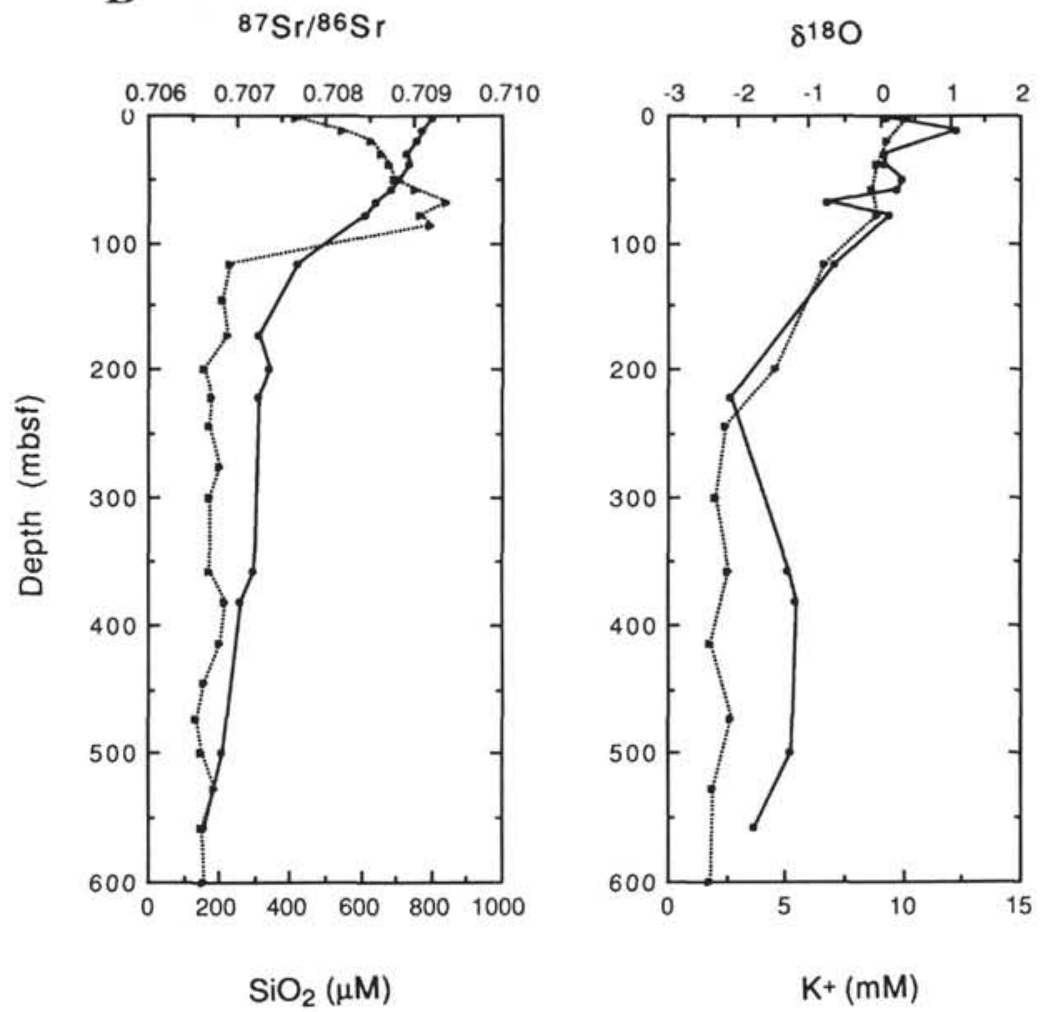

Figure 6. Downcore distributions of strontium and oxygen isotopes (solid lines) for (A) Site 767 and (B) Site 768. Dissolved silica and potassium distributions (dotted lines) are included for comparison. 
PORE-WATER CHEMISTRY OF SULU AND CELEBES SEAS

Table 2. Isotope characterization of the pore fluids from (A) Site 767 and (B) Site 768.

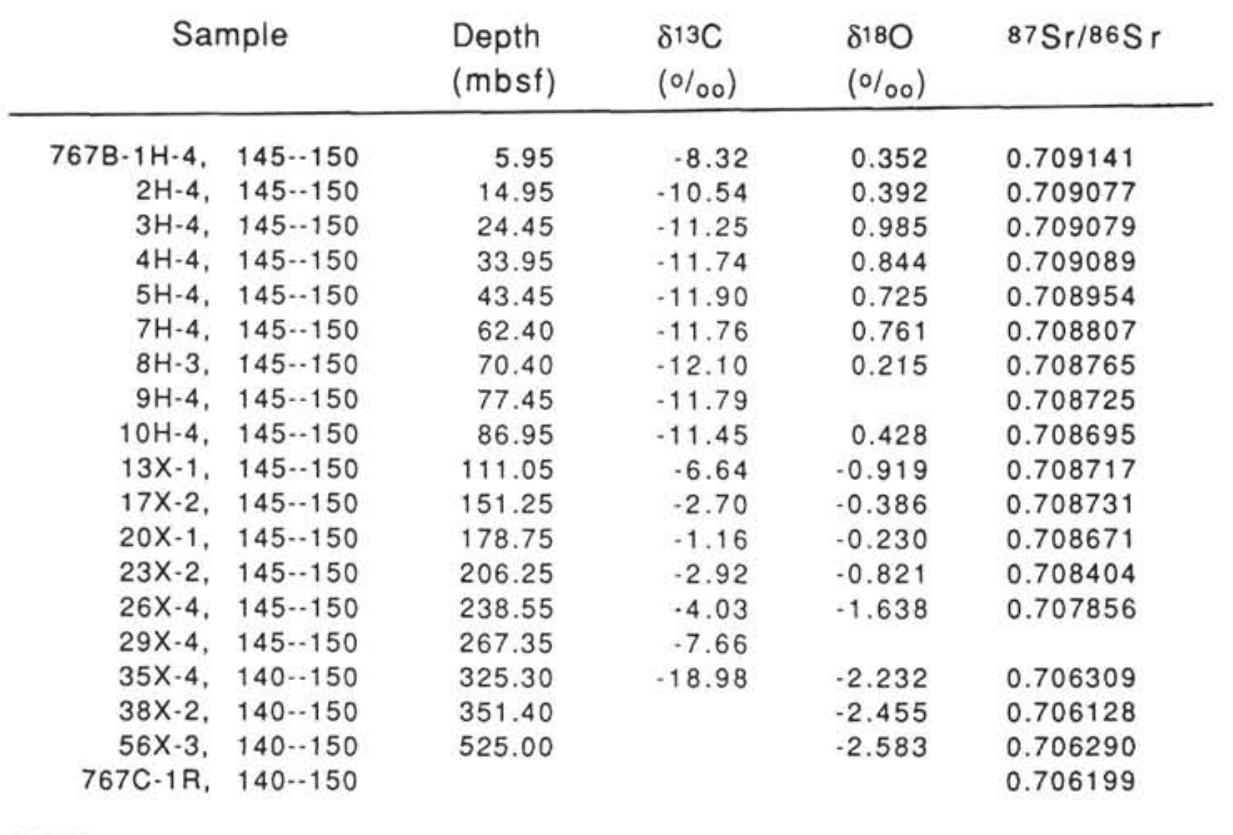

Table 2 (continued).

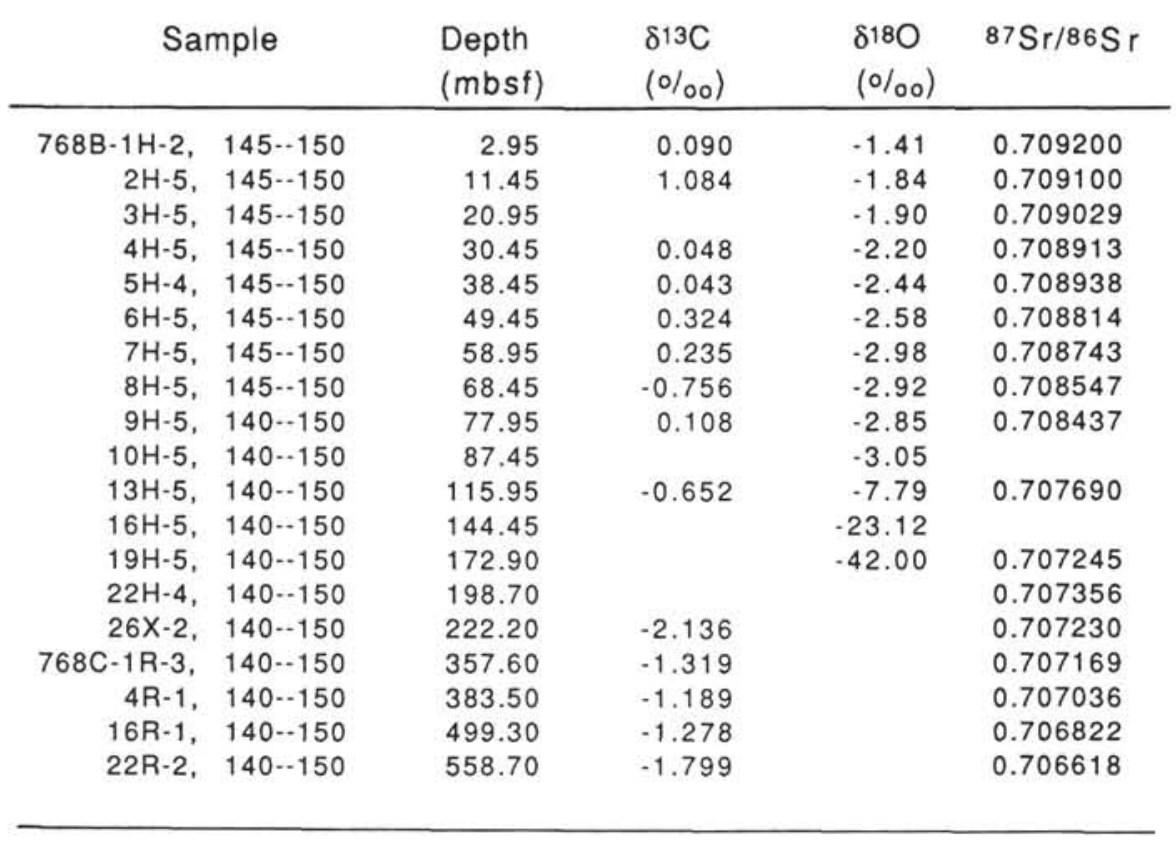

$$
\Delta \mathrm{SO}_{4}^{2-}=1 / 2 \Delta \mathrm{Ca}^{2+}-\Delta \mathrm{Mg}^{2+}-\Delta \Sigma \mathrm{CO}_{2},
$$

which, as shown in Figure 10, corresponds well with the actual observed change in the pore-water sulfate.

The above discussion indicates that the main mechanism driving the calcium and magnesium profiles in Interval I of Sites 767 and 768 is related to carbonate geochemistry, mainly triggered by oxidation of methane and precipitation of dolomite. However, this zone is coincident with high accumulations of ash at both sites. Alteration of this material was evident in petrographic observations (Rangin, Silver, von Breymann, et al., 1990) and constitutes a source of calcium and a sink for silica and magnesium.
Despraires et al. (this volume) conducted geochemical and mineralogical analysis of the volcanic ashes at both sites to determine the nature of the secondary volcanic products in these sequences. They showed that the largest diagenetic effects occur in tephras dated 3.5 to $4 \mathrm{Ma}$, which correspond to a zone between 233 and 329 mbsf at Site 767 and 129 to 165 mbsf at Site 768. The alteration is characterized by a complete replacement of glass by a phillipsite-smectite assemblage. The zeolites show a very low $\mathrm{Ca}$ content relative to $\mathrm{Na}$ and $\mathrm{K}$. Authigenic smectites were shown to consist of a mixture of species ranging from aluminous beidelite to nontronite. These smectites display a positive correlation between potassium and iron and are characterized by low magnesium content. 

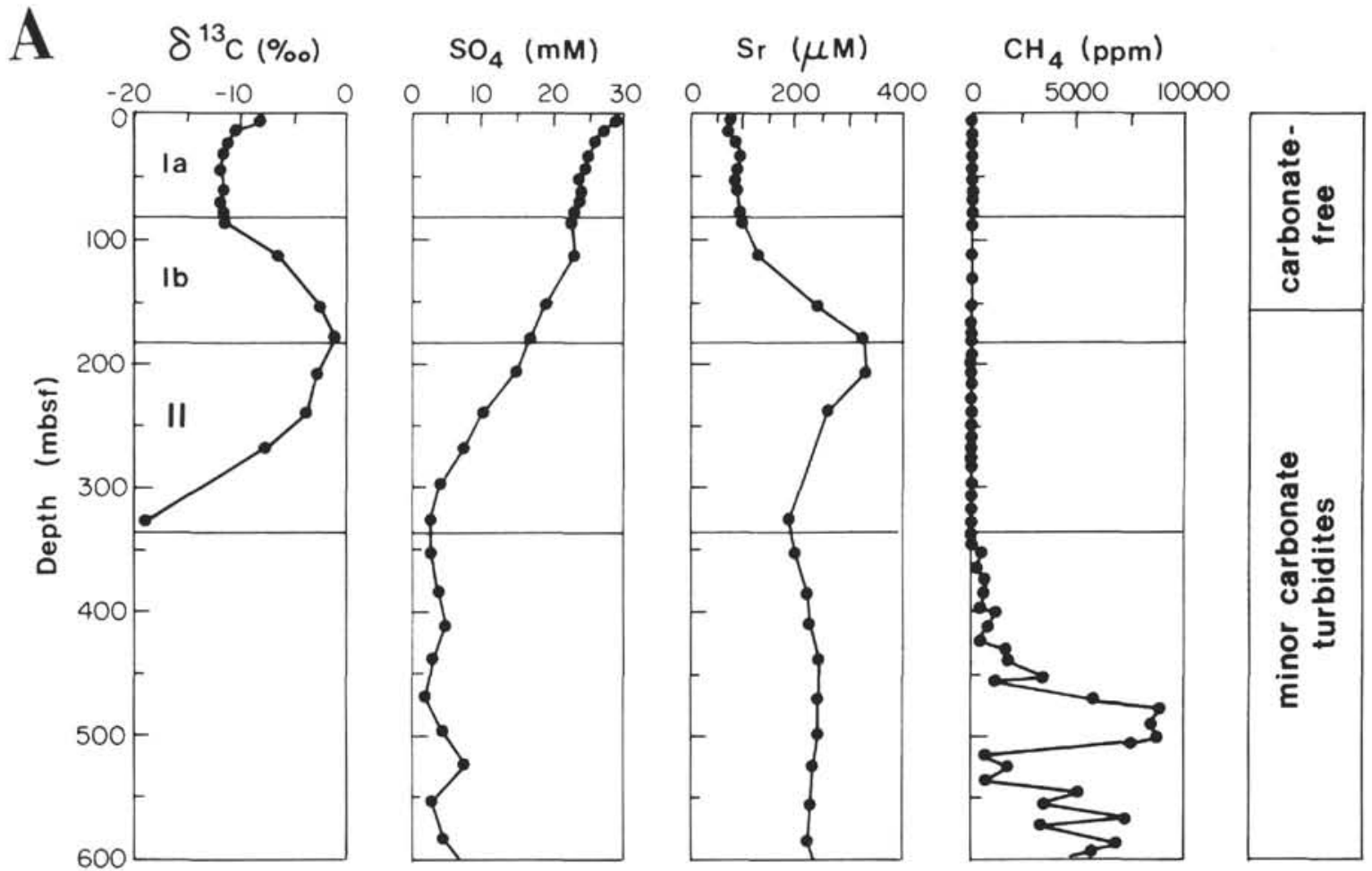

B
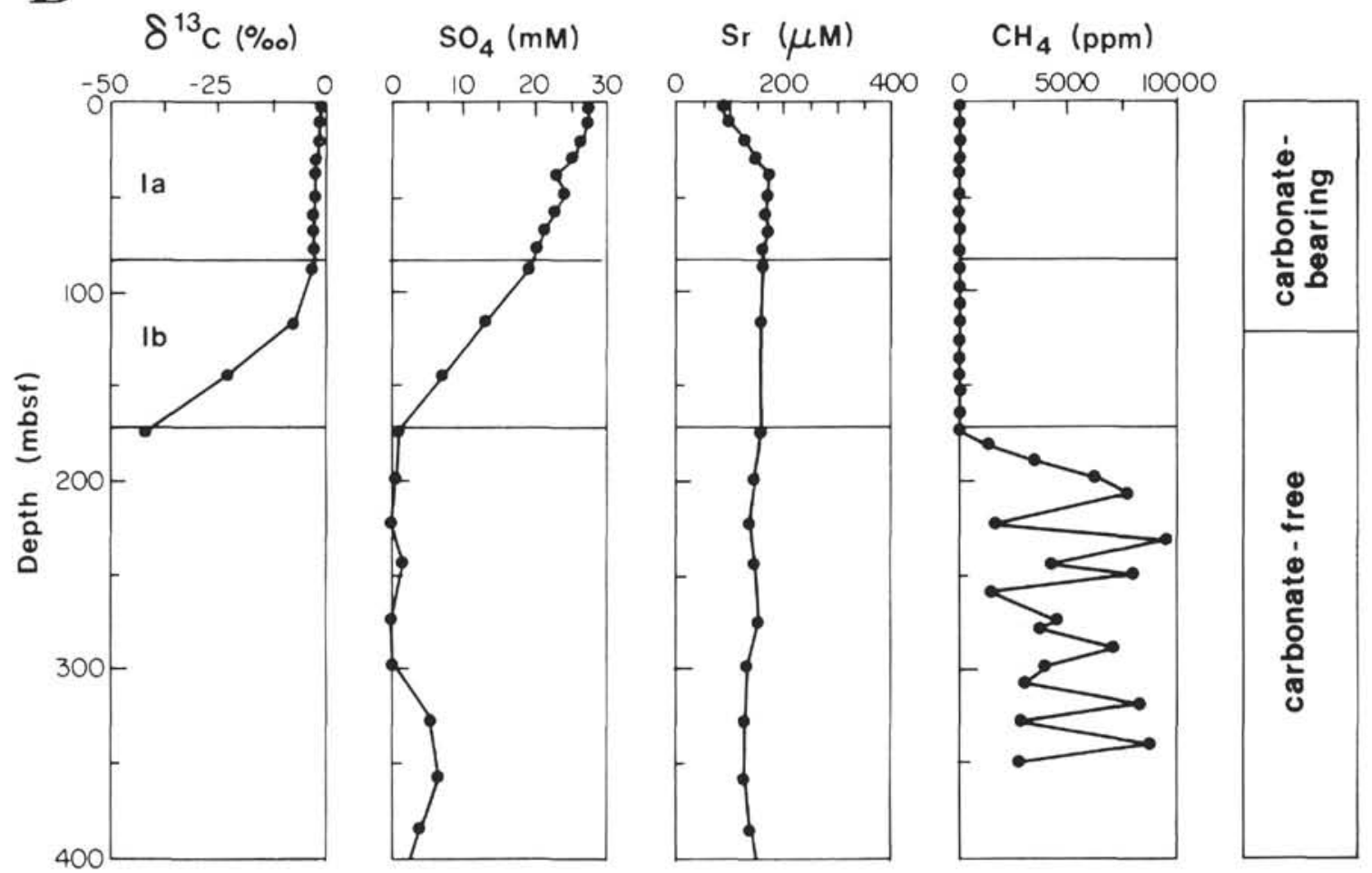

Figure 7. Downcore distribution of $\delta^{13} \mathrm{C}$ of the dissolved $\mathrm{CO}_{2}$ in the pore fluids of (A) Site 767 and (B) Site 768. Dissolved sulfate and strontium profiles, as well as the methane content of the sediments, are included for comparison. 

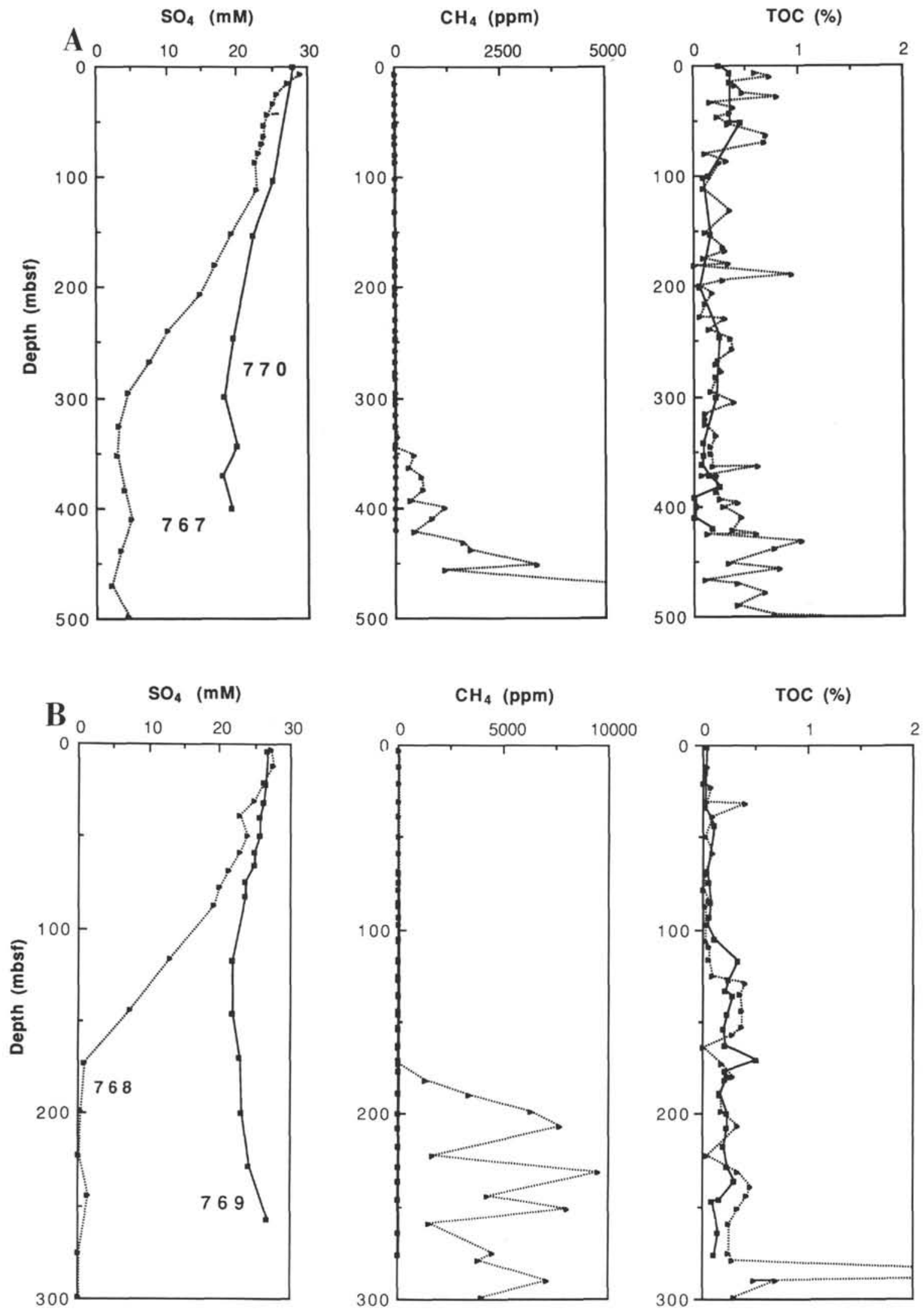

Figure 8. A. Sulfate, methane, and total organic carbon for sites in the Celebes Sea. Site 770 (solid line) is on a bathymetric high relative to Site 767 (dotted line). B. Sulfate, methane, and total organic carbon for sites in the Sulu Sea. Site 769 (solid line) is on a bathymetric high (Cagayan Ridge) relative to Site 768 (dotted line). 


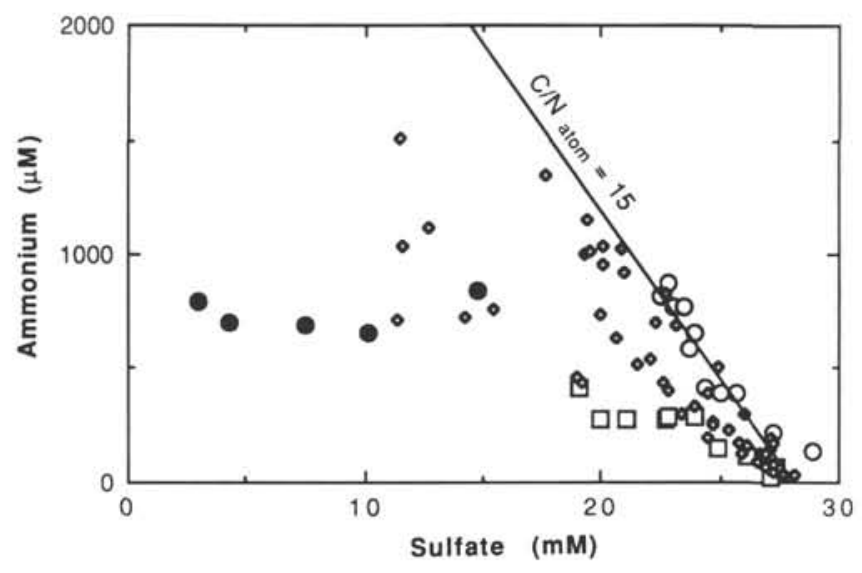

Figure 9. Dissolved sulfate vs. ammonium in the pore fluids. The line represents ammonium generated from microbial sulfate reduction of normal sedimentary organic matter (equation 5); it is based on a regeneration ratio corresponding to a $\mathrm{C} / \mathrm{N}=15$. Samples from Site 767 , Interval Ia (open circles) lie within this line, indicating oxidation of organic matter. The samples from Sites 767 , Intervals Ib and II (closed circles) and Site 768, Interval Ia (open squares) denote samples with strong negative ammonium anomalies compared with the observed sulfate reduction. This deficit reflects the lack of ammonium released from the anaerobic oxidation of methane (equation 2). The small diamonds represent data from the Oregon margin where $\mathrm{CH}_{4}$-derived $\Sigma \mathrm{CO}_{2}$ in the pore fluids has been thoroughly documented (Suess and Whitticar, 1989).

It is hard to estimate quantitatively the extent of these reactions on the magnesium distribution because the silica uptake from the pore fluids is very small, and there is an unknown but small amount of silica available via dissolution of biogenic components. A mass balance using average data for the composition of the original glass (Pouclet et al., this volume), as well as for the authigenic smectite (Desprairies et al., this volume), allows us to estimate the change in silica to magnesium molar ratio during alteration. This value corresponds to a $\% \mathrm{Si}: \Delta \mathrm{Mg}=0.89: 0.26$. Given that these sediments are very poor in biosiliceous components (Rangin, Silver, von Breymann, et al., 1990), and that the secondary clay minerals have a low magnesium content, ash alteration reactions are thought to have a small effect on the magnesium distribution. Dolomitization reactions are therefore likely to constitute the main sink for this cation within the sediment, as evidenced by the results shown in Figure 10.

\section{Interval III}

Even though the formation of secondary phillipsites constitutes a sink for potassium within the sediments, this element is also incorporated into celadonites, an alteration product observed in the pyroclastic sequences at Site 768 (Rangin, Silver, von Breymann, et al., 1990). There is a good correlation between the $\delta^{18} \mathrm{O}$ and the potassium distributions (Fig. 11A), which is in accordance with the fact that the alteration of igneous components results in oxygen isotope fractionation and potassium uptake.

A good relationship between a decrease in the $\delta^{18} \mathrm{O}$ values and a calcium increase has been observed in the pore fluids of DSDP sites where the chemistry of the interstitial fluids is thought to be controlled by alteration of Layer 2 basalts (Gieskes and Lawrence, 1981). At Sites 767 and 768, Intervals I and III show two distinct slopes for the $\mathrm{Ca}-\delta^{18} \mathrm{O}$ relationship (Fig. 11B). Interval 1 , although it has a $2.5 \%$ change in the $\delta^{18} \mathrm{O}$ value, shows virtually no change in the dissolved calcium

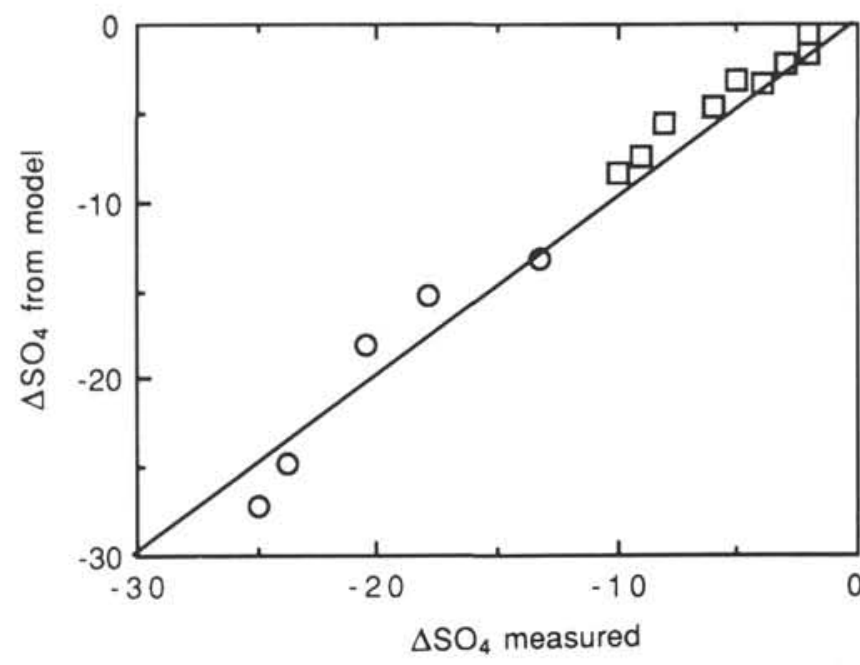

Figure 10. Estimated changes in the sulfate concentration (mM) relative to seawater, vs. measured values at Site 767 , Interval Ib (circles) and Site 768, Interval Ia (squares).
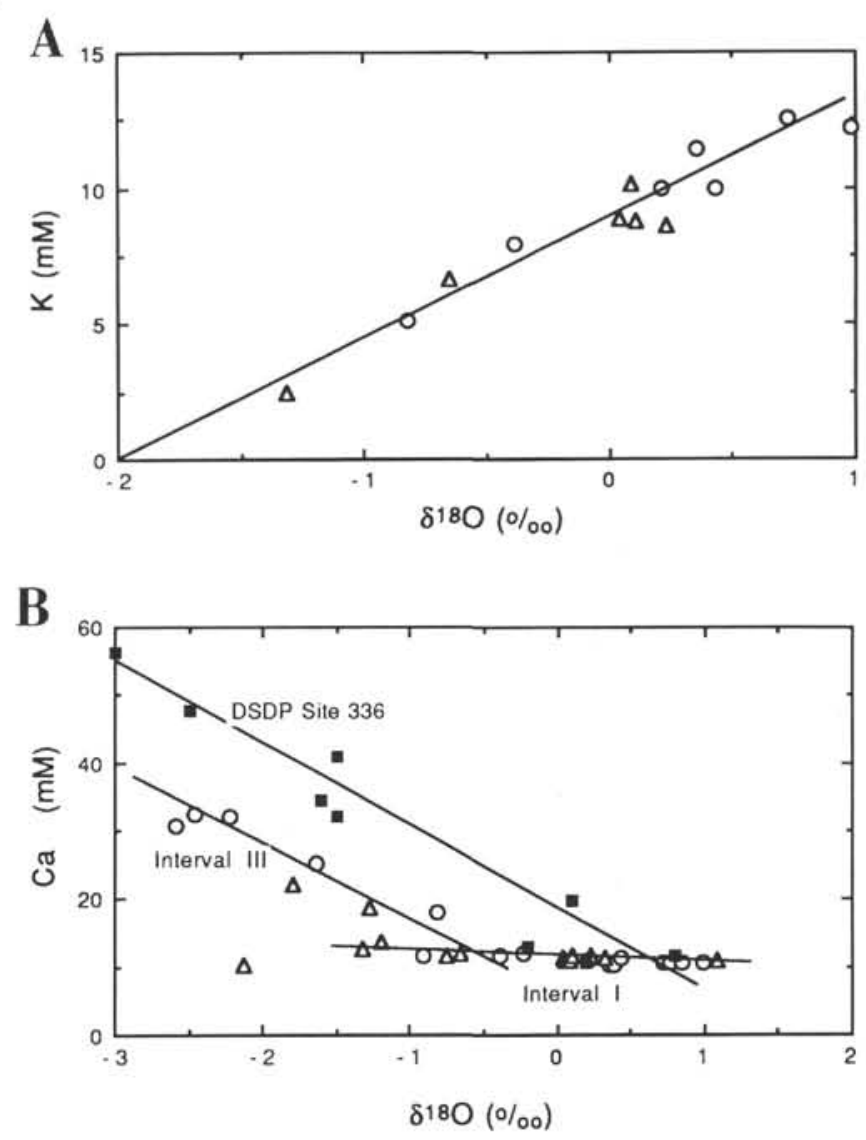

Figure 11. A. Potassium vs. $\delta^{18} \mathrm{O}$ for Sites 767 (circles) and 768 (triangles). B. Calcium vs. $\delta^{18} \mathrm{O}$ for Sites 767 (circles) and 768 (triangles). Data from DSDP Site 336 (squares) are included for comparison. See text for discussion.

concentration, reflecting the fact that ash alteration reactions do not result in significant changes in the concentration of this cation. The slope of the $\mathrm{Ca}-\delta^{18} \mathrm{O}$ relationship for Interval III is 


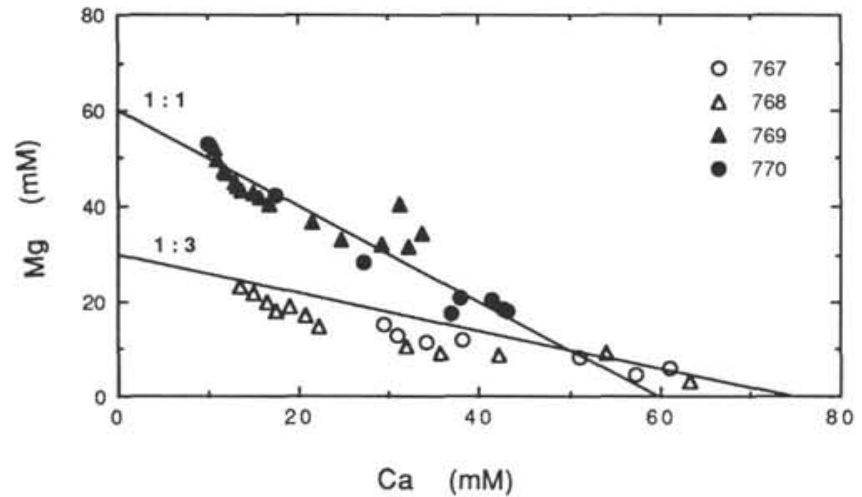

Figure 12. Relationship between calcium and magnesium for Sites 769 and 770 , as well as for Interval III of Sites 767 and 768 .

compared in Figure 11B with that for DSDP Site 336 drilled on the Iceland-Faeroe Ridge during Leg 38 (Lawrence and Gieskes, 1981). The data indicate that in Interval III the main mechanism controlling the calcium and oxygen isotope distributions is the alteration of volcanic sequences underlying the sediment column at Sites 767 and 768 .

Carbonate-related diagenetic processes consume a significant amount of the dissolved magnesium from the pore fluids (Fig. 2) via dolomitization reactions. This has a potential effect on the nature of the alteration products in the basalt and pyroclastic sequences. At Site 769 on the Cagayan Ridge, where there are no $\mathrm{CH}_{4}$ accumulations and thus no likely carbonate sink for the dissolved magnesium, this element is mainly consumed by the alteration of basalts (Rangin, Silver, von Breymann, et al., 1990). Correspondingly, at this site, $\mathrm{Mg}$-rich smectites are the main minerals replacing the glass (R. Smith, this volume). A system depleted in dissolved magnesium may be conducive to the formation of celadonites, an alteration product observed at Site 768 but not at Site 769. Secondary smectites are also present at Site 768 ; these authigenic clay minerals may have formed by alteration reactions that occurred before the rapid turbidite deposits of the middle Miocene or by isochemical transfer of magnesium by the replacement of forsteritic olivine by hydrous ferric oxides (Bohlke et al., 1980).

These different alteration reactions are also suggested by the $\mathrm{Ca} / \mathrm{Mg}$ ratios in the pore waters. Sites 769 and 770 show a $1: 1$ ratio between the calcium production and the magnesium uptake, while the pore fluids of Interval III in the deep basin sites show a 3:1 correlation (Fig. 12). The lower magnesium availability at Sites 767 and 768 results in a different uptake ratio of this cation relative to calcium during alteration reactions relative to Sites 769 and 770 .

\section{ACKNOWLEDGMENTS}

We thank M. Kurtz for use of the facilities for strontium isotope analysis at Woods Hole Oceanographic Institution. The authors thank J. Leder and B. Haldane of the stable isotope laboratory at the University of Miami for assistance in preparing samples and for helpful discussions. In addition, we acknowledge the scientific members and crew of ODP Leg 124 for their assistance, in particular we thank the ODP chemistry technicians J. Powers and M. A. Cusimano for their skillful and conscientious participation in the shipboard geochemical work. This research was supported by grants from the JOI/ USSAC support program to $M$. T. von Breymann and G. Brass.

\section{REFERENCES}

Baker, P. A., 1986. Pore-water chemistry of carbonate-rich sediments, Lord Howe Rise, Southwest Pacific Ocean. In Kennett, J. P., von der Borch, C. C., et al., Init. Repts. DSDP, 90: Washington (U.S. Govt. Printing Office), 1249-1256.

Baker, P. A., Gieskes, J. M., and Elderfield, H., 1982. Diagenesis of carbonates in deep-sea sediments: evidence from $\mathrm{Sr}^{2+} / \mathrm{Ca}^{2+}$ ratios and interstitial dissolved $\mathrm{Sr}^{2+}$ data. J. Sediment. Petrol., 52:71-82.

Berner, U., Bertrand, P., and Scientific Party of Leg 124, in press. Evaluation of the paleogeothermal gradient at Site 768 (Sulu Sea). Geophys. Res. Lett. Böhkle, J. K., Honnorez, J., HonnorezGuerstein, B. M., 1980. Alteration of basalts from site 396B, DSDP: petrographic and mineralogical studies. Contrib. Mineral. Petrol., 73:341-364.

Burke, W. H., Denison, R. E., Hetherington, E. A., Koepnick, R. B., Nelson, H. F., and Otto, J. B., 1982. Variation of seawater ${ }^{87} \mathrm{Sr}{ }^{86} \mathrm{Sr}$ throughout Phanerozoic time. Geology, 10:516-519.

Devol, A. H., 1983. Methane oxidation rates in the anaerobic sediments of Saanich Inlet. Limnol. Oceanogr., 28:738-742.

Emerson, S., and Bender, M., 1981. Carbon fluxes at the sediment water interface of the deep sea: calcium carbonate preservation. $J$. Mar. Res., 39:139-162.

Epstein, S., and Mayeda, T., 1953. Variation of ${ }^{18} \mathrm{O}$ of waters from natural sources. Geochim. Cosmochim. Acta, 4:213-224.

Gieskes, J. M., and Lawrence, J. R., 1981. Alteration of volcanic matter in deep-sea sediments: evidence from the chemical composition of interstitial waters from deep-sea drilling cores. Geochim. Cosmochim. Acta, 45:1687-1703.

Lawrence, J. R., Drever, J. I., Anderson, T. F., and Brueckner, H. K., 1979. Importance of alteration of volcanic material in sediments of Deep Sea Drilling Site 323: chemistry, ${ }^{18} \mathrm{O} /{ }^{16} \mathrm{O}$ and ${ }^{87} \mathrm{Sr} /{ }^{86} \mathrm{Sr}$. Geochim. Cosmochim. Acta, 43:573-588.

Lawrence, J. R., and Gieskes, J. M., 1981. Constraints on water transport and alteration in the oceanic crust from the isotopic composition of pore water. J. Geophys. Res., 86:7924-7934.

McCorkle, D. C., 1987. Stable carbon isotopes in deep sea pore waters: modern geochemistry and paleoceanographic applications. [Ph.D. dissert.]. Univ. Washington, Seattle.

McDuff, R. E., and Gieskes, J. M., 1976. Calcium and magnesium profiles in DSDP interstitial waters: diffusion or reaction? Earth Planet. Sci. Lett., 33:1-10.

Rangin, C., Silver, E. A., von Breymann, M. T., et al., 1990. Proc. ODP, Init. Repts., 124: College Station, TX (Ocean Drilling Program).

Stout, P. M., 1985. Interstitial water chemistry and diagenesis of biogenic sediments from the eastern equatorial Pacific. In Mayer, L., Theyer F., Thomas, E., et al. Init. Repts. DSDP, 85: Washington (U.S. Govt. Printing Office), 805-820.

Suess, E., and Whiticar, M. J., 1989. Methane-derived $\mathrm{CO}_{2}$ in pore fluids expelled from the Oregon subduction zone. Palaeogeogr., Paleoclimatol., Palaeoecol., 71:119-136.

Swart, P. K., and Guzikowski, M., 1988. Interstitial-water chemistry and diagenesis of periplatform sediments from the Bahamas, ODP Leg 101. In Austin, J. A., Jr., Schlager, W., et al., Proc. ODP, Sci. Results, 101: College Station, TX (Ocean Drilling Program), 363380 .

Vollbrecht, R., and Kudrass, H. R., 1990. Geological results of a pre-site survey for ODP drill sites in the SE Sulu Basin. In Rangin, C., Silver, E. A., von Breymann, M. T., et al., Proc. ODP, Init. Repts., 124: College Station, TX (Ocean Drilling Program), 105-111.

von Breymann, M. T., and Berner, U., 1990. Diagenetic dolomite formation in the Sulu and Celebes seas from continentally derived turbidite deposits rich in organic matter. Trans. Am. Geophys. Union, 71:1392 (Abstract).

Whiticar, M. J., and Faber, E., 1986. Methane oxidation in marine and limnic sediments and water columns. 12th Intl. Mtg. Organic Geochem. 1985, Juelich. In Leythaeuser, D., and Rullkotter, J. (Eds.), Advances in Organic Geochemistry (Vol 10): New York, (Springer-Verlag), 759-768.

Date of inital receipt: 3 July 1990

Date of acceptance: 11 February 1991

Ms 124B-154 